\title{
Introduction to Thematic Symposium on Accounting Professionalism
}

\author{
Sally Gunz ${ }^{1} \cdot$ Linda Thorne $^{2}$
}

Received: 28 February 2016/ Accepted: 26 March 2016/Published online: 20 April 2016

(C) Springer Science+Business Media Dordrecht 2016

The five papers and their discussant comments that follow are the product of the Symposium conducted by the Centre for Accounting Ethics, University of Waterloo, in Toronto, Canada, May 2015. The theme of both the Symposium and this collection of papers is accounting professionalism. The motivation for the Symposium was to increase our insights and understanding of the key factors that shape accounting professionalism today. More specifically, the intent was to increase our understanding of the factors that impact accounting professionalism and to explore how shifting notions of professionalism might impact the role of accounting in society and the delivery of accounting services. Many of the themes flowing through the papers in this collection can be traced to the critical work of Zeff (2003a, b). It was particularly fitting therefore that Dr. Zeff gave the plenary presentation at the Symposium.

One underlying assumption shared by this collection of papers is that professionalism in accounting is evolving and responding to continual changes in the regulatory, social, and economic environment in which the profession operates. Although previous research has provided insight into the factors that influence accounting professionalism, additional work is needed to ensure that professionalism and ethics remain at the forefront as core values for the

Linda Thorne

lthorne@ schulich.yorku.ca

Sally Gunz

sgunz@uwaterloo.ca

1 School of Accounting and Finance, Centre for Accounting Ethics, University of Waterloo, Waterloo, ON N2L 3G1, Canada

2 Schulich School of Business, S342, York University, 4700 Keele Street, Toronto, ON M3J 1P3, Canada accounting profession. Perhaps, the relevance and the need for continued investigation and exploration into accounting professionalism is best highlighted by the continuation and frequency of accounting scandals that have been uncovered during the first decade of the twenty-first century [for example, Enron (2001), WorldCom (2002), Tyco (2002), Freddie Mac (2003), HealthSouth (2003), AIG (2005), Lehman Brothers (2008), Madoff (2008), Saytam (2009)] and which show no signs of abating. ${ }^{1}$ Organizational and institutional responses to these scandals have transformed the contextual landscape that defines accounting professionalism.

This collection of papers provides insight into professionalism as currently exercised by professional accountants in public practice and in industry. The findings support Zeff's (2003a, b) argument that the accounting profession and its exercise of professionalism are negatively and seriously impacted by the need to deliver services in an era of commercialism. ${ }^{2}$ This era is typified by an emphasis on profitability and revenue growth with the public interest becoming only a secondary consideration of the professional. Not surprisingly (arguably inevitably),

\footnotetext{
${ }^{1}$ For example, arguably little has changed in terms of the underlying flaws in the rating systems that were an integral part of the 2008 financial collapse (Morgensen 2016).

${ }^{2}$ Zeff (1987, 2003a, b) provides an overview of the evolution of the accounting profession. Zeff (2003a, b) presented a typology of the three stages of the evolution of the accounting profession: formation, institutionalization, and commercialization. The first stage, formation, occurred prior to 1940 and was characterized by the formulation and the development of accounting professionalism. The second stage, institutionalization, lasted from the 1940s to the mid-1960s when professional accountants set accounting standards and there was little question of the ethicality of professional accountants. The third stage, commercialization, involved increased emphasis on consulting practices and revenue growth in the accounting firms.
} 
accounting oversights and scandals have not abated despite extensive efforts to impose regulatory reform. The resulting risk is that of an erosion in society's positive perceptions of accountants' professionalism (Zeff 2003b). The recent work by Ramanna (2015) explores the relationship between an escalation in scandals and commercialism and the proliferation of financial regulation introduced in order to reinforce the importance of public interest for accounting professionals.

The papers that follow examine accounting professionalism in the era of commercialism, and expand our existing understanding in several critical ways. Three papers consider the interplay between the evolution in organizational and institutional structures influencing professional accountants and accountants' professionalism. In the first paper, Fiolleau and Kaplan (2016) consider the critical role of the corporate reward structure on the ethical sensitivity of accountants. Professional accountants work in a range of occupational contexts. While the accounting firm has been the most obvious context in which the issues of professionalism have been explored, it is equally important to consider, for example, the challenges faced by the professional management accountant operating in an employment context. Fiolleau and Kaplan (2016) explore the impact of compensation structures on professional accountants and on earnings management among accountants in industry (and students). They approach their study using an unusual 'funnel questioning technique'. Their findings suggest that, not surprisingly, compensation structures influence the professional accountants' ability to recognize ethical dilemmas and hence influence accountants' professionalism.

In the second paper, some key insights into the role of organizations and institutions in defining accounting professionalism are presented by Brouard et al. (2016). They present a theoretical framework that explores the reciprocal influence and formation of the identity, image, and stereotypes of professional accountants as defined by various factions. These factions delineate the stereotypical characteristics of accountants' professionalism. These stereotypes are crucial not only to defining the ethical behavior and the professionalism of current members of the profession, but also to attracting future members.

Our third paper explores the influence on professionalism of a recent emphasis on accounting specialization being adopted in public accounting firms. Specialization is a facet of audit expertise that is being increasingly adopted throughout the audit profession. It is based upon the presumption that auditor specialization increases audit quality. In an examination of this assumption, Grenier (2016) examines the extent to which specialization impacts auditor skepticism, and in so doing, ultimately impacts audit quality. Grenier's (2016) study identifies circumstances where industry experts are less inclined to be skeptical in analyzing audit evidence. Grenier's findings suggest that industry knowledge and the inherent self-confidence of the auditor result in lower skepticism under circumstances where indicators of higher misstatement exist. While these circumstances, by definition, do carry lower risk, they are also ones in which the PCAOB suggests fraud may occur. On the other hand, Grenier (2016) does find evidence that shows that accounting specialists are more skeptical when prompted as compared to generalists, and less skeptical when not prompted as compared to generalists.

While without doubt the accounting profession has been subject to an array of environmental and organizational changes (e.g., internal changes in the accounting environment such as increased specialization, increased pressure from and for globalization, deskilling pressures from technology), perhaps the greatest change has been to regulation (Cooper and Robson 2006). The accounting profession belongs to the body of self-regulating professions that historically has possessed a monopoly that bestows both economic power and social status (Suddaby and Muzio 2014). The fourth and fifth papers in our collection provide insight into the interplay between regulation and accounting professionalism.

The fourth paper is presented by Mescall et al. (2016) who investigate the link between observable signals of possible impairments of public accountant independence (e.g., Ye et al. 2011) and the impact of firms' commercial dependence on clients (e.g., Li 2009; Ruddock et al. 2006). The authors compare sanctions imposed on auditors before and after the creation of the Canadian Public Accountability Board (CPAB) in 2003. They show that the creation of an oversight body resulted in increased severity of discipline for members of the accounting profession by comparing the disciplinary committees' recommendations with respect to misconduct violations before and after the creation of the CPAB. Finally, the authors' review of internal and external disclosures of disciplinary actions suggests that the accounting profession continued to emphasize their own commercial interests over that of the public even after the creation of CPAB.

The fifth paper presents an interesting examination of the relationship between the accounting profession and regulation. Baudot et al. (2016) extend the groundwork laid by Zeff $(2003 \mathrm{a}, \mathrm{b})$ by considering the extent to which the accounting profession influenced the financial regulation that defined the boundaries and the profitability of the accounting monopoly. More specifically, Baudot et al. (2016) examine the advocacy efforts of the AICPA as reflected in lobbying reports and comment letters directed to politicians and regulators. They show that both public and private interests were reflected in the lobbying efforts, with three distinct objectives in mind: (1) controlling 
expertise/authority, (2) preserving socio-economic status, and (3) protecting professional jurisdiction. The authors conclude that the accounting profession faces an ethical crisis as it actively influences the regulation that governs the monopoly by which it is expected to serve the public interest.

Following each paper, readers will find comments from the respective discussants. These academics have followed the evolution of each paper and their original comments at the Symposium were incorporated into all stages of the various revisions. The discussants have provided their critical perspectives on what each paper contributes to the literature and where future research might take the specific projects. These are a critical component of this complete collection.

The findings presented by our collection of papers and commentaries explore how some of the recent pressures and challenges impacting the accounting professional influence ethical decision making and professionalism. The impact of these pressures on accounting professionalism continues to be an important topic for investigation as researchers strive to understand the factors that shape the accounting profession and accounting professionalism (c.f., Denison et al. 2014). Our collection considers the interface between the accounting profession and regulation in this era of commercialism in a variety of organizational contexts, and shows the continued need for regulators to impose boundary conditions to ensure that accounting professionalism remains paramount. The ever-changing institutional landscape places greater importance on developing a theoretical understanding of how to ensure and promote the ethics and professionalism of the accounting profession (Suddaby et al. 2007; Suddaby and Muzio 2014).

\section{References}

Cooper, D. J., \& Robson, K. (2006). Accounting, professions and regulation: Locating the sites of professionalization. Accounting, Organizations and Society, 31(4), 415-444.

Denison, C. A., Ravenscroft, S. P., \& Williams, P. F. (2014). Accounting and public policy: The importance of credible research. Accounting and the Public Interest, 14, 113-127.

Li, C. (2009). Does client importance affect public accountant independence at the office level? Empirical evidence from going-concern opinions. Contemporary Accounting Research, 26(1), 201-230.

Morgensen, G. (2016, January 8). Ratings agencies still coming up short, years after crisis. The New York Times. Retrieved from http://www.nytimes.com/2016/01/10/business/ratings-agenciesstill-coming-up-short-years-after-crisis.html?_r=1

Ramanna, K. (2015). Political standards: Accounting for legitimacy. Chicago: University of Chicago Press.

Ruddock, C., Taylor, S. J., \& Taylor, S. L. (2006). Nonaudit services and earnings conservatism: Is public accountant independence impaired? Contemporary Accounting Research, 23(3), 701-746.

Suddaby, R., Cooper, D., \& Greenwood, R. (2007). Transnational regulation of professional services: Governance dynamics of field level organizational change. Accounting, Organizations and Society, 32, 333-362.

Suddaby, R., \& Muzio, D. (2014). Theoretical perspectives of the professions. Working Paper.

Ye, P., Carson, E. \& Simnett, R. (2011). Threats to public accountant independence: The impact of relationship and economic bonds. Auditing: A Journal of Practice \& Theory, 30(1), 121-148.

Zeff, S. A. (1987). Does the CPA belong to a profession. Accounting Horizons, 1(2), 65-68.

Zeff, S. A. (2003a). How the US accounting profession got where it is today: Part I. Accounting Horizons, 17(3), 189-205.

Zeff, S. A. (2003b). How the U.S. accounting profession got where it is today: Part II. Accounting Horizons, 17(4), 267-286. 